\title{
Article \\ Sediment Distribution and Treatment in the Inflow Water-Level-Fluctuating Zone of the Biliuhe Reservoir
}

\author{
Guangyu Su ${ }^{1}$, Shiguo $\mathrm{Xu}^{1}{ }^{1} *$, Yu Liu ${ }^{1}$, Huijuan $\mathrm{Yu}^{2}$ and Baoquan $\mathrm{Mu}^{3}$ \\ 1 The Institution of Water and Environment Research, Dalian University of Technology, Dalian 116024, China; \\ sugy@mail.dlut.edu.cn (G.S.); dlutstudents@163.com (Y.L.) \\ 2 Research Institute for Environmental Innovation (Binhai, Tianjin), Tianjin 300452, China; hjyzyn666@163.com \\ 3 Management Bureau of Biliuhe Reservoir, Dalian 116000, China; mbq95@163.com \\ * Correspondence: sgxu@dlut.edu.cn
}

check for

updates

Citation: Su, G.; Xu, S.; Liu, Y.; Yu, H.; $\mathrm{Mu}, \mathrm{B}$. Sediment Distribution and

Treatment in the Inflow Water-LevelFluctuating Zone of the Biliuhe

Reservoir. Water 2022, 14, 580.

https://doi.org/10.3390/w14040580

Academic Editor: Sheldon Masters

Received: 28 December 2021

Accepted: 10 February 2022

Published: 14 February 2022

Publisher's Note: MDPI stays neutral with regard to jurisdictional claims in published maps and institutional affiliations.

Copyright: (C) 2022 by the authors. Licensee MDPI, Basel, Switzerland. This article is an open access article distributed under the terms and conditions of the Creative Commons Attribution (CC BY) license (https:// creativecommons.org/licenses/by/ $4.0 /)$.

\begin{abstract}
Most of the pollutants carried by runoff accumulate in the form of sediment, impacting the capacity and water quality of reservoirs. To study the sediment distribution in the water-levelfluctuating zone (WLFZ) of a reservoir in North China with a long drying period and to explore its treatment, the Biliuhe Reservoir in Dalian, Liaoning Province, China, was selected as the study area. The sediment thicknesses along the thalwegs of the three tributaries were surveyed, including a detailed survey on the sediment thickness and particle size in Dapu, the inflow bay of the main river. According to our findings, the sediment distribution along the thalwegs is similar to the delta sedimentation. The inflow WLFZ, especially the inflow bay, is the main gathering area for sediment. Furthermore, the variation in sediment thickness in the top-set region has river siltation characteristics, which are mainly affected by the scouring and deposition of floods during the dry period. From the convex bank to the inside of the bay in Dapu, the hydrodynamic force of the sediment gradually weakens, the thickness gradually increases, and the bay is the main sedimentary area of the suspended load. A method of sediment reuse for vegetation buffer platform construction is proposed. This method can reduce the amount of sediment entering downstream and enhance the ability to remove the pollution along the bank of the reservoir.
\end{abstract}

Keywords: reservoir; sediment distribution; inflow water-level-fluctuating zone; inflow bay; vegetation buffer platform

\section{Introduction}

The construction and operation of reservoirs change the natural runoff processes of rivers and block the transportation of pollutants along with the runoff downstream. Therefore, reservoirs play a significant role in collecting pollutants carried by runoff, especially during floods. Most of these pollutants accumulate in the form of sediment, which impacts the capacity and water quality of the reservoir. China is the country with the most serious reservoir deposition problem, with an annual average deposition rate of $2.3 \%$ [1], while the global average is $0.5-1 \%$ [2]. This means that without effective action, one-quarter of the world's reservoirs will lose their storage to sedimentation in the next 25 to 50 years [3], and that this process will take less than 11 years in China. In addition to the reduction in reservoir capacity, the endogenous pollution caused by sediment accumulation after long operation has become a widespread water quality issue. The water supply of Guanting Reservoir in Beijing and Tanghe Reservoir in Liaoyang was once affected by sediment pollution [4]. Therefore, it is of great significance for the extension of reservoir service life and water quality protection to understand the distribution of sediment in reservoirs, to find and predict concentrated sedimentation zones, and explore reasonable treatment solutions.

Reservoir sedimentation is a complex process that varies with terrain and water storage. The mechanisms contributing to reservoir sedimentation are well known, but 
their physical contents are not yet fully understood theoretically [5]. According to the nonequilibrium theory of sediment transport, Han et al. divided reservoir sedimentation into three categories, delta siltation, vertebral siltation, and belt siltation, and established a mathematical model for sedimentation [6]. Delta siltation is considered to be the most common deposition pattern in reservoirs. It can be described as being formed by three regions, from upstream to downstream: top-set, fore-set, and bottom-set [7,8]. Fan and Morris studied the delta of Guanting Reservoir, Shanyiujiang reservoir, and Sanmenxia Reservoir, and analyzed the factors affecting the sedimentary form of the delta [9]. Lai and Capart proposed a simple morphodynamic theory of reservoir deltas prograding over bedrock, which they verified through the development process of the delta in Wushe reservoir [10]. Taking the Suchedniów reservoir as an example, Łukasz BK studied the sediment distribution characteristics of this small reservoir and found that existing methods could not accurately predict the sediment distribution [11]. In recent years, with the development of computer technology, the simulation of reservoir sediment has become a research focus. A numerical model [12], an artificial neural network [13], and 1d, 2d, and $3 \mathrm{~d}$ models [14-17] have been applied to the simulation of reservoir sediments.

The water level of the studied reservoirs fluctuates periodically between the flood control level and the normal water level. Most of the time, when floods enter the reservoir, the water level is near the flood control level. Consequently, the end of the permanent backwater region is the main deposition area. Current studies also focus on the sediment in permanent backwater regions. However, the level of precipitation in North China is low and unevenly distributed in time and space. To adapt to the characteristics of incoming water, the reservoirs in this region often have high capacity adjustment coefficients, which also led to large fluctuations in water levels, long variation periods, and even lower water level operation for many years. Furthermore, the inflow water-level-fluctuating zone may be the main area of deposition. Compared with the permanent backwater region, the surface of the inflow water-level-fluctuating zone is strongly scoured by runoff during the drying period, making the sediment distribution more complex and changeable. Furthermore, the sediment is carried downstream by runoff. The long drying period in the water-level-fluctuating zone also provides favorable conditions for the land dredging of sediment, which is low in cost and highly efficient. However, the study of the sediment survey and treatment in the inflow water-level-fluctuating zones of reservoirs in North China is rare.

The aims of this study were: (i) to explore the distribution characteristics of the sediment in the inflow water-level-fluctuating zone, including those along the thalweg and in the inflow bay, which is the main deposition area; and (ii) to put forward treatment by land dredging and the nearby utilization of sediment as a resource. The Biliuhe Reservoir in Dalian, Liaoning Province, China, was selected as the study area. The sediment surveys along the thalwegs and in Dapu were carried out during the drying period, and the distribution characteristics were analyzed, as well as the particle size distribution of the sediment in Dapu. The land-dredged sediment was used for vegetation buffer platform construction, reducing the amount of sediment entering downstream and controlling coastal non-point source pollution, and the determination methods of the key parameters were studied.

\section{Materials and Methods}

\subsection{Study Area}

Biliuhe Reservoir is a large (II) reservoir built on the main stream of Biliuhe River in the north of Dalian. The confluence area on the dam is $2068 \mathrm{~km}^{2}$, with a total storage capacity of 930 million $\mathrm{km}^{3}$. It is the central water source of Dalian. At present, the water quality of the reservoir generally meets the class II standard, meeting the requirements of drinking water quality. However, there are also problems, such as the total nitrogen exceeding the standard, and iron and manganese exceeding the standard regionally and seasonally. It is a river-type reservoir with three main tributaries, named Biliu River, Geli River, and Bajia 
River. According to the sediment monitoring data of the Jianchang Hydrological Station upstream of the reservoir on the Biliu River from 2006 to 2017, the turbidity of the river is lower than the detection limit for most of the daily time, and the sediment is mainly carried into the reservoir by floods. The reservoir area is narrow and zigzagged. The floods in the basin rise and fall sharply, with high peak and rapid flow. The climate of the basin is a typical temperate monsoon climate [18]. The rainfall from June to August accounts for $75 \%$ of the annual total, and the interannual distribution of the rainfall is uneven [19]. Affected by the annual distribution of rainfall, the reservoir water level generally shows rapid growth in the flood season and a gradual decline in the non-flood season. According to the historical water level at the beginning of the decade, from 1985 to 2017, the average water level of the reservoir is $60.28 \mathrm{~m}$ in the beginning of July, while the flood control level is $68.1 \mathrm{~m}$, meaning that floods in the early flood season often enter the reservoir when the water level is low.

Dapu is the inflow bay of the Biliu River. The area is surrounded by mountains to the east, west, and south, a village to the north, and a flood runoff outlet of the village on the northeast corner. The main stream of the Biliu River is on the west side of the area, and the river section has a turning angle close to $310^{\circ}$, forming a bay with weak hydrodynamic force to the east. In the vertical flow direction, the flow pattern varies greatly. The area's terrain is flat, and the ground elevation is $61.40 \mathrm{~m}-67.00 \mathrm{~m}$. According to the reservoir water level before 281 floods from 1985 to 2015, the water level before 89 floods was lower than $61.4 \mathrm{~m}$ which is the lowest elevation in Dapu, and the water level before 131 floods was in the range of $61.4 \mathrm{~m}-67.00 \mathrm{~m}$, which is the elevation range of Dapu. During most floods, some areas are exposed to water in Dapu, making the sediment deposition complex.

\subsection{Investigation, Sampling, and Analyses}

The sediment thickness surveys were conducted in the inflow water-level-fluctuating areas of the Biliu River, Geli River, and Bajia River from July to October in 2017, taking advantage of the low water level in the reservoir. In total, 17 survey points were arranged along the thalweg in the inflow water-level-fluctuating zone of Biliu River, and 8 survey points were arranged along the thalwegs in the inflow water-level-fluctuating zone of Geli River and Bajia River, respectively (Figure 1). In addition to the survey points along the thalwegs, 28 survey points were arranged in Dapu. The height difference between the ground and the interface between the clay layer and the middle sand layer in the vertical sections, which were the sections beside the main channels or elf-excavated, was used as the sediment thickness [20]. The self-developed gravity sediment measuring instrument was used to measure the sediment thickness in the permanent backwater region, and six survey points were arranged. The main body of the self-developed gravity sediment measuring instrument is a bar with non-penetrating holes on both sides. After the instrument falls into the sediment, the sediment samples at various depths are collected by the holes as the protective sleeve mechanism is triggered, thereby acquiring stratification information about the underwater sediment [21]. Sediment cores were sampled from the 16 survey points in Dapu. After excavation, the vertical surface in contact with the spade was removed with a stainless-steel shovel before sampling. All sediment cores were sliced at $2 \mathrm{~cm}$ intervals for the upper $20 \mathrm{~cm}$, at $5 \mathrm{~cm}$ intervals for $20-50 \mathrm{~cm}$, and at $10 \mathrm{~cm}$ for the rest. Sampling stopped when the interface between the clay layer and the middle sand layer was encountered [22]. Next, the collected samples were transported to the laboratory in polyethylene bags, air-dried, ground, and sieved below $2 \mathrm{~mm}$. Samples with depths of $4-6 \mathrm{~cm}, 14-16 \mathrm{~cm}, 25-30 \mathrm{~cm}$, and 50-60 cm were selected for particle size analysis. The particle size distribution was analyzed by a laser particle size analyzer (Malvern Instrument Company, Malvern, United Kingdom, Mastersizer 2000), and the range of particle detection was $0-2 \mathrm{~mm}$ [23]. 


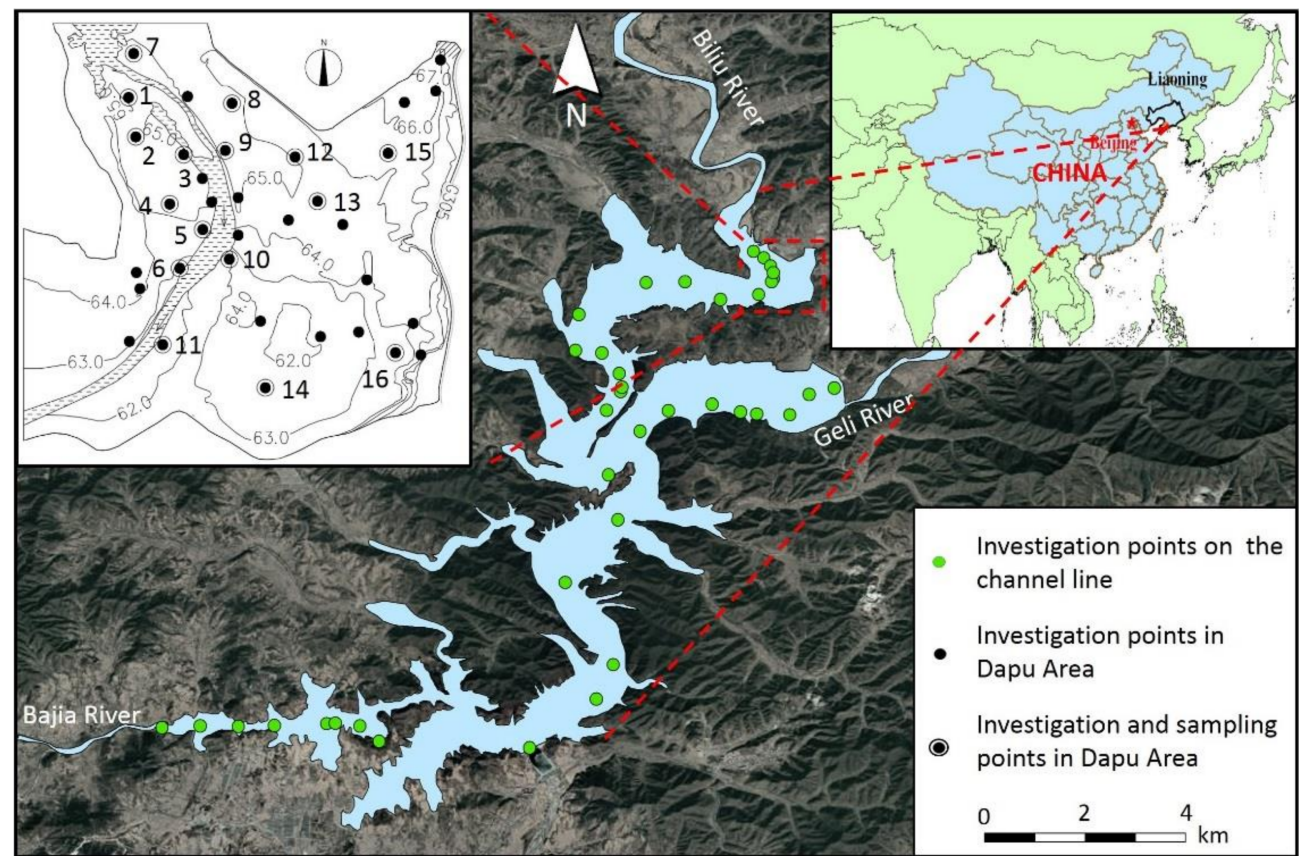

Figure 1. The distribution of the survey points.

\subsection{Sediment Particle Size Characteristics Analysis Method}

The peak numbers of particle size frequency curves were counted and the particles were classified by Udden-Wentworth standard, according to the particle size distribution. The particles were divided into clay $(<0.0039 \mathrm{~mm})$, silt $(0.0039-0.0625 \mathrm{~mm})$, and sand $(0.0625-2 \mathrm{~mm})$ [24]. According to the classification results, a Morten Pejrup triangle diagram was created to reflect the hydrodynamic force of each point through the composition of the sediment structure [25]. Firstly, the sediments were divided into four groups, A, B, C, and D, by $10 \%, 50 \%$, and $90 \%$ of sand content. Next, the sediments were divided into I, II, III, and IV four groups by $20 \%, 50 \%$ and $80 \%$ of silt/(silt + clay) [26].

\subsection{Data Analysis}

Data processing was performed using Excel 2013, ArcGIS 10.1 was used for sediment thickness interpolation analysis, and ArcGIS 10.1 and AutoCad2010 were used for figure preparation.

\section{Results}

\subsection{Sediment Thickness Variation along the Thalwegs}

The sediment thicknesses and reservoir width in the water-level-fluctuating zone along the thalwegs of the reservoir are shown in Figure 2. The distribution of sediment along the thalwegs of the three tributaries is similar to delta sedimentation [27]. The top-set region and fore-set region are all in the water-level-fluctuating zone, and the sediment thickness in the bottom-set region stabilizes at a lower value. Although the water-level-fluctuating zone of Biliuhe Reservoir has a long drying time, the initial sections of the tributaries are still the main sedimentary area of sediment. Overall, the sediment thicknesses along the thalwegs decreases gradually from the entrance to the front of the dam. The sediment thickness fluctuates greatly in the top-set region, which is different from the common delta sedimentation. In the top-set region, the variation trend of the sediment thickness along the thalweg is consistent with that of the reservoir width: with the increase in reservoir width, sediment thickness increases, and vice versa. 


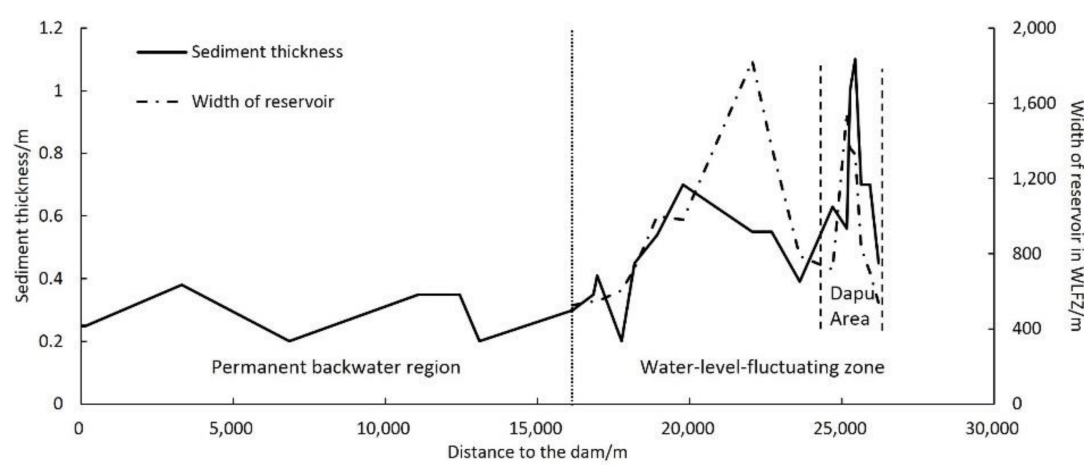

(a)

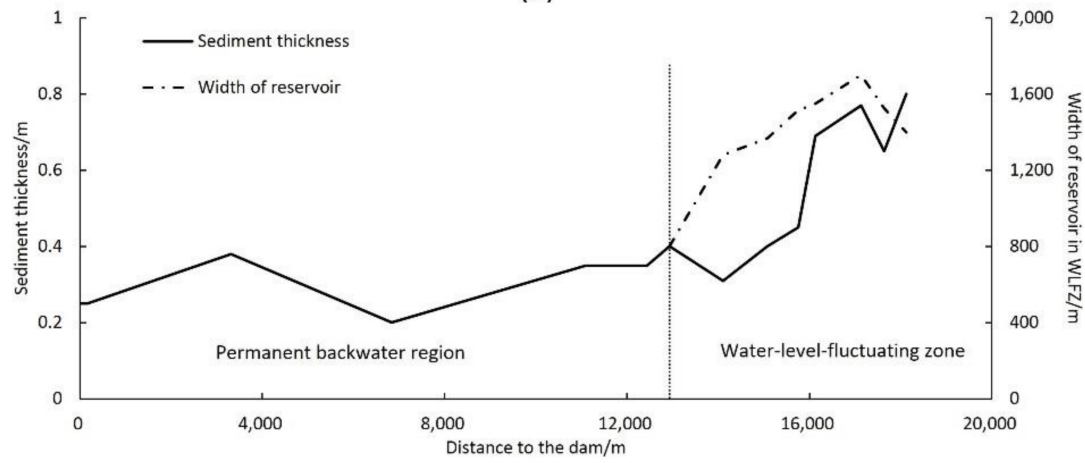

(b)

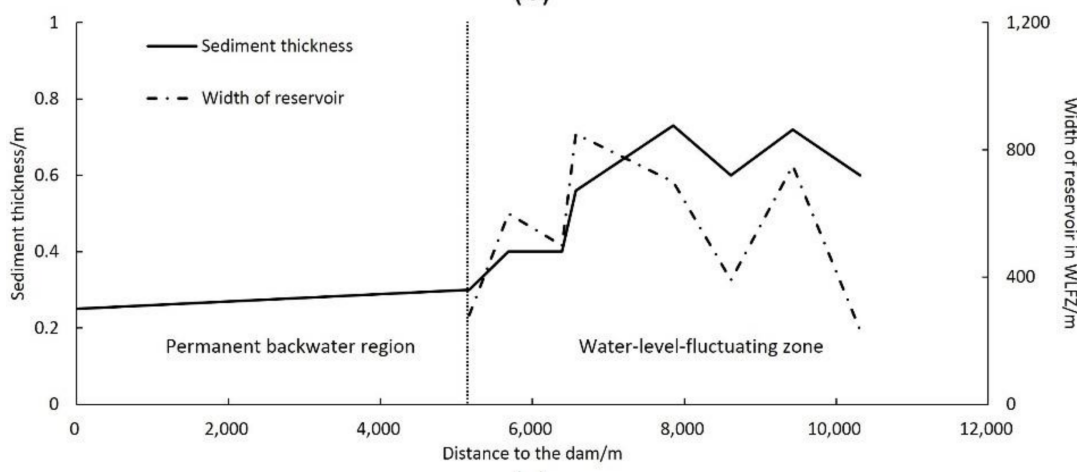

(c)

Figure 2. Sediment thicknesses and the width of the reservoir in the WLFZ along the thalwegs of: (a) the Biliu River, (b) the Geli River, and (c) the Bajia River.

In Dapu, the peak sediment thickness is much higher than in other areas. In addition to the influence of reservoir width, the bay in Dapu is likely to play an essential role in the accumulation of sediment.

\subsection{The Sediment Distribution in Dapu}

\subsubsection{The Distribution of Sediment Thickness in Dapu}

The sediment thickness distribution in Dapu is shown in Figure 3. Sediment was deposited at all the survey points, including the points on the right bank as the convex side of the area. The sediment thicknesses of the survey points range from 0.2 to $1.3 \mathrm{~m}$. According to the simulation results of the sediment thickness, the total sediment amount in Dapu is 1.55 million $\mathrm{m}^{3}$. According to the hydrological characteristic value in the scheduling manual of Biliuhe Reservoir, the annual average sediment discharge is 259.1 kilotons. Since the reservoir began operating in 1986, the total operation time of the reservoir, as of 2017, was 31 years, and the total amount of sediment in the reservoir was 8.03 million tons, equivalent 5.02 million $\mathrm{m}^{3}$. That is to say, the sediment in Dapu was about $30.88 \%$ of the total amount of sediment in the reservoir. 


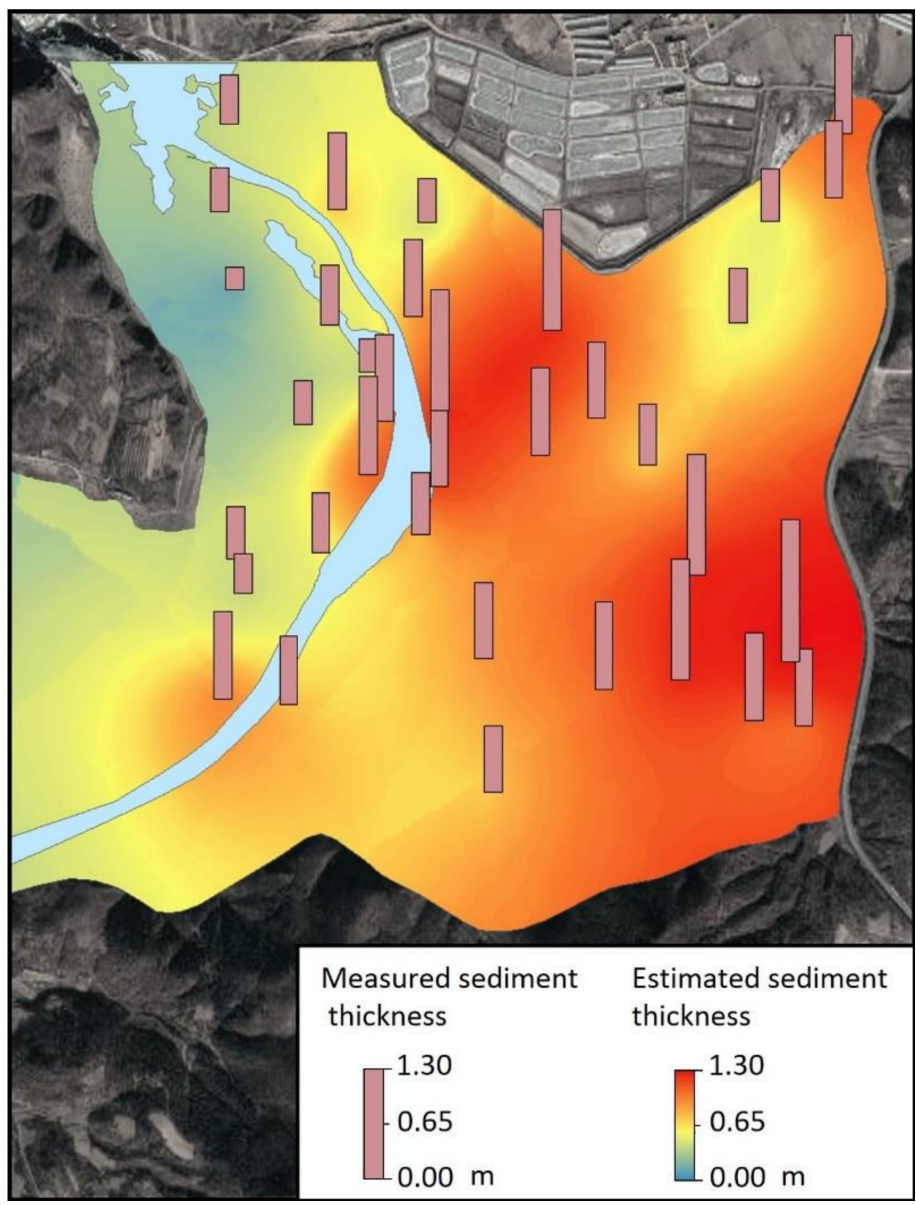

Figure 3. Sediment thickness in Dapu.

The sediment thickness on both sides of the main stream is consistent with the change in width of the reservoir section, showing a trend of first increasing and then decreasing. The sediment thickness of the left bank is higher than that of the right bank in the upper and middle reaches, and the sediment thickness on the right bank is gradually higher than that on the left bank downstream. This is consistent with the trend in which the convex bank shifts from the right bank to the left bank downstream.

In the direction perpendicular to the river, the average sediment thickness of the right bank is $0.38 \mathrm{~m}$, which is much lower than that of the left bank, $0.78 \mathrm{~m}$, without considering the survey points beside the main stream. The sediment thickness increases gradually from the convex bank to the bay on the concave bank, and the concave bank is the main sedimentary area in the inflow bay.

\subsubsection{Sediment-Particle Size Distribution}

The sediment composition and peak number of each sample in Dapu are shown in Figure 4. Compared with the sediment in the permanent backwater region, the sediment in Dapu has higher sand content and lower clay content. By contrast, the silt content changes little, indicating that its particle size is larger, which is consistent with previous research [28,29]. Points 1-7, 11, and 12, with high sediment sand content, are located in the right bank and the upstream and downstream of the left bank, respectively. Points 15 and 16 , with the lowest sediment sand content, are located in the inner part of the bay, and the sand content of some samples is close to that of the samples in the permanent backwater region. The particle size frequency curves of the samples are mainly bimodal, the curves of the samples at Points 1,2, and 4 on the right bank are mainly unimodal, and the curves of the samples of Points 12,14 and one of Point 6, 7, and 13 feature three peaks. 


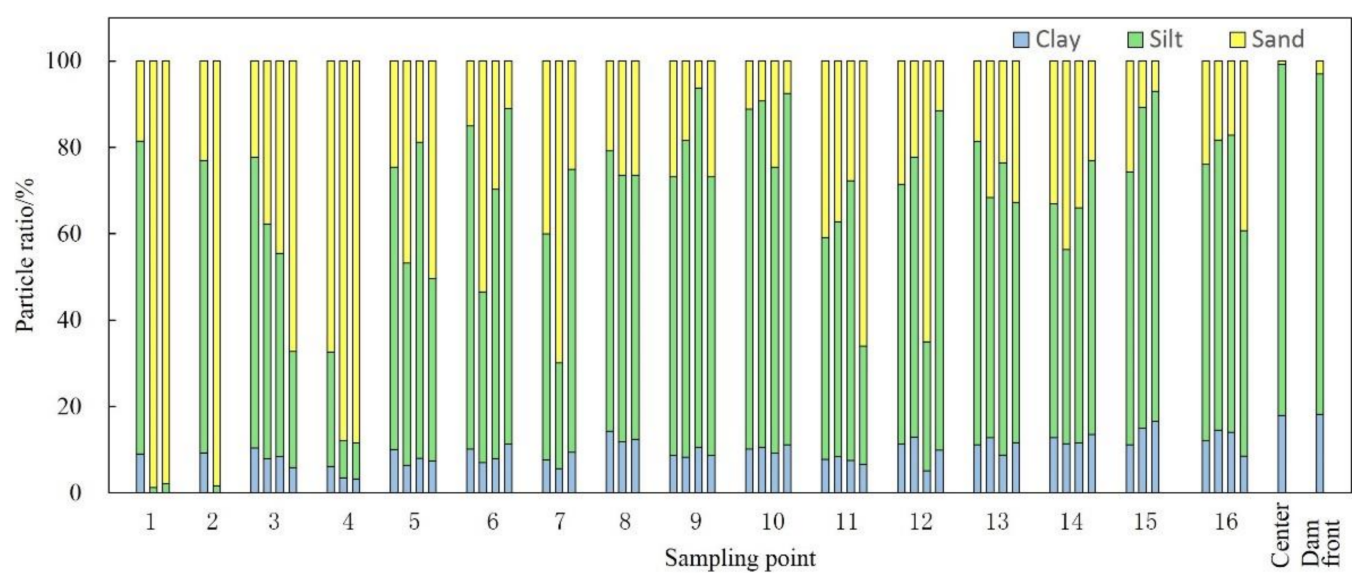

Figure 4. Sediment composition and peak number at each point in Dapu.

\section{Discussion}

\subsection{The Main Influencing Factors on Sediment Distribution in the Water-Level-Fluctuating Zone}

The hydrodynamic conditions, turbidity currents, and waves are considered to be the three main factors affecting the distribution of reservoir sediment [30]. The turbidity currents are considered to be the main mechanism for distal sediment transport within reservoirs [5], and the turbidity currents have little effect on the distribution of sediments in the WFLZ. The hydraulic conditions are the main factors affecting the initial deposition of sediment. Waves mainly affect the redistribution of sediment.

The Morten Pejrup triangle of the samples in Dapu (Figure 5) shows that the hydrodynamic forces beside the main stream and on the right bank are the strongest, followed by the central part of the bay, and that the hydrodynamic force at the inner part of the bay is the weakest. There is an obvious negative correlation between the variation trend of the hydrodynamic force and sediment thickness in Dapu. This supports the above inference.

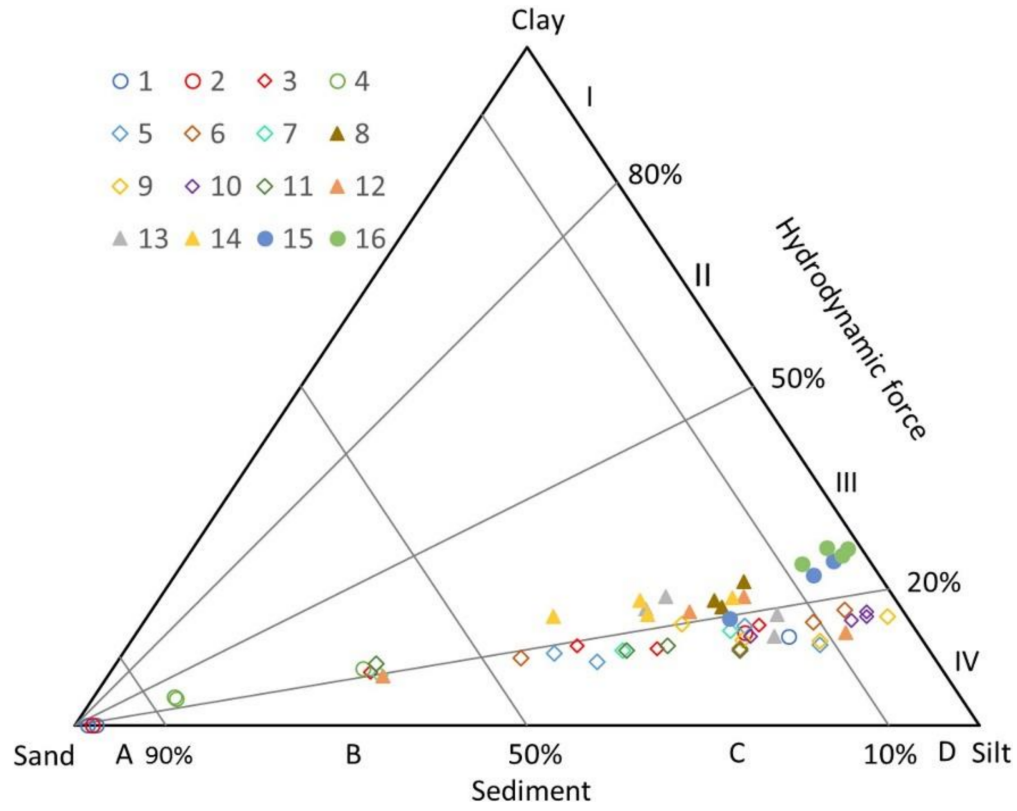

Figure 5. The Morten Pejrup triangle of the samples (the symbol $\bigcirc$ is used for the points on the right bank, the symbol $\diamond$ is used for the points beside the main stream, the symbol $\boldsymbol{\Delta}$ is used for the points on the middle-left bank, and the $\bullet$ symbol is used for the points on the inner-left bank).

The variation trend of sediment thickness in the top-set region along the thalweg is consistent with that of the reservoir width, which is known to be negatively correlated with the flow velocity. The sediment-carrying capacity of the river flow is positively correlated with the flow velocity [31]. This is similar to the sediment distribution in the river [32] and 
inconsistent with the typical deposition patterns in the theory of the non-equilibrium of suspended sediment transportation in reservoirs $[33,34]$. In the area downstream of Dapu, the sediment thickness decreases significantly and then increases. It was inferred that it may be formed by the combined action of the scouring of runoff during the drying period and sedimentation during the flooding period. This may also simply be due to the reduced sedimentation during floods. In Dapu, the sand contents of the points in the middle reaches of the left bank are low, while the sediment sand content of Point 11 is high. The sorting of particle size is likely to be caused by the runoff scouring due to the conversion of the convex and concave bank downstream and the narrowing of the reservoir section. In view of the higher sand contents of the sediment at Points 1-7, which are on the convex bank upstream, it can be inferred that the convex bank is scoured by floods during the drying period. The decrease in sediment thickness in the area downstream of Dapu is also probably due to runoff scouring during the drying period.

Due to the scouring by runoff, a deep main stream was formed in Dapu, and no sediment was deposited at the bottom. According to historical satellite images, the main stream was stable and had not changed since the construction of the reservoir, but the depth had gradually increased. The points with lower levels of sediment thickness on the left bank of Dapu are mainly distributed in the diagonal area from northeast to southwest, and other points have uniform sediment thickness. It can be seen from the terrain that the ground elevation of this area is lower than that of the surrounding area, which makes the area the main path of the village flood runoff. As the distance from the village flood runoff outlet increases, the sediment thickness increases. Therefore, it can be inferred that the lower sediment thickness in this area is caused by village flood runoff scouring during the drying period. It can be inferred from the surrounding Points that the sediment thickness in this area would be more than $1 \mathrm{~m}$ without scouring. It can be seen that the scouring by runoff of surface sediment in the drying period can cause a large amount of sediment in the upstream to migrate downstream, but the secondary distribution effect of scouring by daily runoff and small floods on sediment mainly acts on the main stream, so the main runoff stream should receive more attention during treatment.

Waves mainly affect the redistribution of fine particles. There is a lack of wind and wave monitoring data in the reservoir. The impact of wind and waves can only be inferred from the sediment source information in response to the sediment particle size frequency curves. The maximum blowing distance of the waves is less than $3 \mathrm{~km}$ in Dapu and less than $4.5 \mathrm{~km}$ in the inflow water-level-fluctuating zone of the Geli River and Bajia River, due to the narrow, zigzagged shape of the reservoir area. This is likely to result in smaller waves. In Dapu, the peak number in the vast majority of the samples is two, which could be explained by the external source of the sediment, and few peaks occur in the interval of small particles. From this, it can be inferred that the effect of wind and waves on the sediment distribution in Dapu is weak. Based on this, the effect of wind and waves on the sediment distribution in other regions, which all have small maximum blowing distances and even greater water depths, may also be relatively small. This conclusion is different from those of studies on reservoirs with open water [35-37].

\subsection{The Sedimentary Characteristics in the Inflow Bay}

The peak number of the sediment particle size frequency curve can reflect the source of sediment [38]. The unimodal symmetry curve indicates that the sediment has a single source, and the multimodal asymmetry curve indicates that the sediment has multiple sources. The sediment in Dapu is mainly carried by the Biliu River, and a small amount is carried by the village flood runoff. The source of the sediment is relatively uniform. The peak number difference of sediment particle size curves in the region may reflect the sedimentation region of the suspended load and bed load. The particle size frequency curves of the samples are mainly bimodal, which indicates that the sediment is mainly affected by two sources of particles. The samples at Points 1, 2, and 4 on the right bank are mainly unimodal curves. Considering that the sediment is predominantly composed of 
sand, it can be inferred that the sediment is mainly from the bed load of the Biliu River. The samples of Points 12 and 14, and one of Point 6, 7, and 13, have a three-peak curve. Considering the location of Points 12 and 14, it can be inferred that the sediment sources of the two points include the suspended load and the bed load of Biliu River and the suspended load of the village flood runoff. However, only the sediment at the bottom has three peaks at Point 13, which is close to Point 12. This shows that Points 12 and 13 are close to the bed load sedimentation boundary. With the increase in sediment and the formation of the main stream, the sedimentation boundary bed load shrank. Points 15 and 16 , with the lowest sediment sand content, are located in the inner part of the bay, and the sand content of some samples is close to the samples in the permanent backwater region. Therefore, the sediment sources of Points 15 and 16 may be the suspended load of the Biliu River and the village flood runoff. Therefore, it can be inferred that the sediment sources of Points 5-10 are the suspended load and bed load of the Biliu River.

In summary, the bed load is mainly deposited in the entrance and the upper reaches of the right bank, and a small part of the bed load is deposited near the main stream and slightly inside the bay. The suspended load is mainly deposited beside the main stream and in the bay. The sediment in the inner part of the bay is entirely derived from the suspended load of the Biliu River and the village flood runoff. The sedimentary characteristics of the sediment from the Biliu River are similar to those of sediment in the rivers with concave banks [39-41].

\subsection{The Treatment of the Sediment in Dapu}

The inflow water-level-fluctuating zone, especially inflow bay, is the main gathering area of sediment. Sediment impacts water quality during the submerging period and is carried downstream by the runoff during the drying period. With the increase in dry accumulation time, the surface is scoured to form a main stream, and the interception capacity of the sediment for daily inflow and small floods becomes very low. Building a water-blocking structure downstream to keep the area waterlogged can expand the overflow section and reduce runoff scouring, making the area similar to a pre-reservoir, but the impact of the sediment on the quality of the overlying water needs further research. Sediment dredging is a more common method. The sediment concentrations in the inflow water-level-fluctuating zones of the reservoirs in North China provide favorable conditions for low-cost land dredging. The disposal of sediment is the crucial problem of dredging work; nearby reuse is the most reasonable approach. The frequency of dredging should depend mainly on the occurrence of long drying periods, which are influenced by multiyear rainfall. Preferably, all sediment should be removed, and when constrained, the sediment in the areas with strong hydrodynamic forces, such the areas near runoff main streams and on convex banks, should be removed first.

Due to the limitations of terrain, land resources, and other factors, there are often coastlines around reservoirs, and non-point pollution sources such as roads and farmland are close to the water. Due to the lack of isolation space, pollutants directly enter reservoirs, impacting on the water quality and safety. The use of vegetation buffer strips has become an important and widely accepted management tool for controlling diffuse pollution [42] However, the adaptability of vegetation to water-level fluctuation limits its application in reservoirs. Using dredged sediment to form a platform can avoid the influence of waterlevel fluctuation and ensure the utilization of sediment as a resource. Reasonable design can also make it play a variety of roles, such as ecological habitat, entertainment, and landscape. National Highway 305 is connected with the reservoir on the east side of Dapu. The road's runoff pollution and road accidents pose potential threats to the water quality. Using the sediment in Dapu to build a vegetation buffer platform could remove the sediment and reduce the impact of water level fluctuation on the purification and isolation process of vegetation and pollutants by increasing the ground elevation. The key parameters, such as elevation, vegetation, and width, would determine the effect of this buffer platform. 


\subsubsection{Calculation of the Platform Elevation}

Elevation is the decisive factor in guaranteeing the effectiveness of buffer platforms. Platforms work when their elevation is higher than the water level of the reservoir. The reasonable selection of platform elevation, to balance the operation's guarantee rate, and the cost are the primary challenges in buffer platform design. The water level variation is the basis for the platform elevation selection. The formula is:

$$
\mathrm{H}=\mathrm{h}_{1}+\mathrm{h}_{2}+\mathrm{h}_{3}
$$

In the formula, $\mathrm{H}$ is the elevation of the platform $(\mathrm{m}) ; \mathrm{h}_{1}$ is the datum elevation $(\mathrm{m})$, which is selected according to the water-level frequency curve of the reservoir; $h_{2}$ is the reserved height for wind and waves $(\mathrm{m})$; and $\mathrm{h}_{3}$ is the reserved height for land subsidence and other errors $(\mathrm{m})$.

The assurance of the buffer platform in Dapu is not less than 95\%. According to the water-level frequency curve of Biliuhe Reservoir from 1985 to 2005, the frequency of $68.5 \mathrm{~m}$ is $4.67 \%$. Therefore, take $\mathrm{h}_{1}=68.5 \mathrm{~m}$, and take $\mathrm{h}_{2}=0.5 \mathrm{~m}, \mathrm{~h}_{3}=0.5 \mathrm{~m}$, so that $\mathrm{H}=69.5 \mathrm{~m}$.

\subsubsection{Vegetation Selection}

The selection of the vegetation on the buffer platform is also an essential factor affecting the platform's interception of pollutants. The selection of vegetation should follow the principle of combining arbors, shrubs, and herbs, and selecting varieties that are droughtresistant and survive easily under local conditions. Arbors, shrubs, and herbs are generally arranged from the waterside to the inside. Arbors are arranged on the Dapu vegetation buffer platform near the highway for intercepting vehicle accidents beside the reservoir. Guidance by natural survival provides the best approach to selecting the plants to be used [43]. After a long period of natural selection, some dominant species have emerged in the WLFZ. According to the investigation of vegetation, Salix matsudana was chosen as the arbor, Salix integra was chosen as the shrub, and no artificial intervention was carried out on the herbs. The planting space of the Salix matsudana was increased to facilitate the natural growth of herbs.

\subsubsection{Calculation of the Minimum Width of the Platform}

The width of the platform is the determinant of its size, effect, and sediment consumption. Pollutants are gradually detained along the runoff flow path, so the effect of the platform is gradually improved with the increase in width. The proper width of the buffer platform to guarantee the effect is an essential parameter for both pollutant removal and cost control. The requirements of the width of the buffer platform may vary due to differences in function, and the selection basis may also be different.

From the perspective of pollutant interception and the degradation of runoff, current research into vegetation buffer strips shows that a very narrow buffer strip can remove most of the particulates and pollutants adsorbed on it. Furthermore, the retention efficiency of sediment does not increase significantly with increases in width. A buffer strip with a width of $8 \mathrm{~m}$ can meet the needs of particulate retention, but the removal efficiency of soluble compounds increases as the width increases [44-46]. Furthermore, $8 \mathrm{~m}$ can be taken as the minimum width for runoff pollutant interception. Appropriately increasing the width when conditions allow is beneficial for the removal of soluble compounds. The log-normal relationships between buffer strip width and nutrient removal efficiency for total nitrogen (TN) and total phosphorus (TP) are in agreement with previous studies, as well as the linear relationships between the percentage buffer strip slope and the removal efficiency of TN and TP [47-49]. A slight slope can promote runoff and sheet flow, increasing pollutant removal efficiency [50]. Therefore, the buffer strip has an optimal slope to make the removal efficiency the highest possible. When the slope exceeds the optimal level, the removal efficiency decreases with the increase of the slope. When the slope is lower than the optimal 
level, the removal rate increases with the increase of the slope [47]. It can be inferred that the relationship between pollutant removal efficiency, width, and slope is as follows.

$$
\begin{gathered}
\mathrm{y}=\mathrm{a}_{1} \times \ln \mathrm{x}_{1}+\mathrm{b}_{1} \times\left(\mathrm{x}_{2}-\mathrm{S}\right)+\mathrm{c}_{1} \text { while } \mathrm{x}_{2}<\mathrm{S} \\
\mathrm{y}=\mathrm{a}_{2} \times \ln \mathrm{x}_{1}-\mathrm{b}_{2} \times\left(\mathrm{x}_{2}-\mathrm{S}\right)+\mathrm{c}_{2} \text { while } \mathrm{x}_{2} \geq \mathrm{S}
\end{gathered}
$$

In this formula, $\mathrm{y}$ is the removal efficiency for TN and TP, $\mathrm{x}_{1}$ is the platform width, $\mathrm{x}_{2}$ is the platform slope as a percentage, and $b_{2}<b_{1}$.

The parameters can be obtained by experiments or the results of previous studies with similar conditions. Yang measured the removal efficiencies of TN and TP by vegetation buffer strips of different widths and slopes composed of equal-width Salix matsudana, Amorpha fruticosa, and Trifolium repens strips, and established a binary linear regression equation [51]. Given that the minimum width of the mixed Salix matsudana and herbs strip is two times of that of the Salix integra strip, the width of Salix matsudana, Salix integra, and herb strips can be considered equal. Based on the data reported by Yang, Formula (2) can be used to obtain the removal efficiency. A level of $10 \%$ was taken as the best slope percentage [47]. There is a lack of observational data on situations in which the slope is lower than the optimal level, and when the width is large, the slope has a relatively small effect on the removal efficiency. Therefore, $b_{2}=b_{1}$ was selected in this study. In this way, the calculated removal efficiency tends to be lower. The results are shown in Figure 6. The $\mathrm{R}^{2}$ is higher than that reported by Yang. It can be concluded that a width of $24 \mathrm{~m}$ can meet more than $80 \%$ of the requirements of TN and TP removal efficiency when the slope is $0 \%$. Compared with previous studies, the calculated removal efficiencies are within a reasonable range $[47,52,53]$.

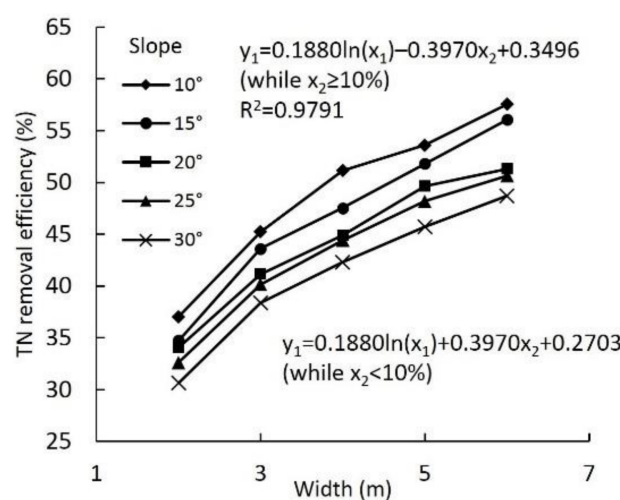

(a)

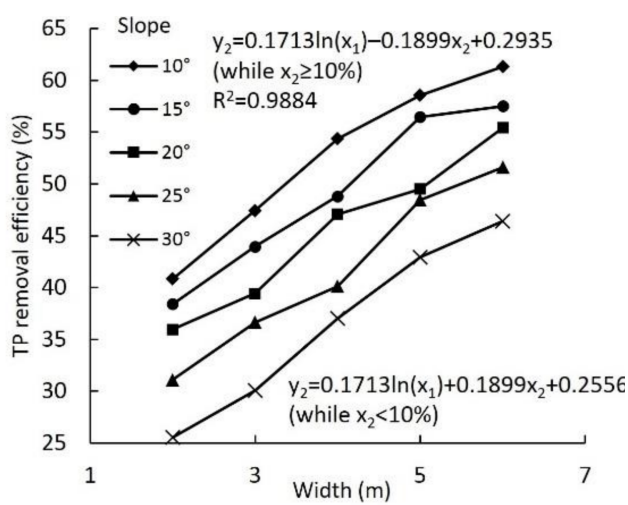

(b)

Figure 6. The relationship between the TN and TP removal efficiencies and the width and the slope. (a) the relationship between TN removal efficiency, riparian buffer width, and slope, where $\mathrm{y}_{1}$ is the removal efficiency of TN; (b) the relationship between TP removal efficiency, riparian buffer width, and slope, where $\mathrm{y}_{2}$ is the removal efficiency of TP.

In addition to isolating the road runoff pollutants, the vegetation buffer platform in Dapu also isolates the road accident leakage pollutants. From the perspective of road accident pollution isolation, the minimum width should be greater than the maximum leakage distance of pollutants. First, the volume of leakage used should be chosen according to the road class and vehicle traffic conditions. Next, according to Formula (4), the leakage liquid pool area can be calculated. The fan-shaped liquid pool radius can finally be calculated as the minimum width required for road accident pollution isolation.

$$
S=W /\left(\rho \times H_{\min }\right)
$$

In the formula, $\mathrm{S}$ is the pool area $\left(\mathrm{m}_{2}\right), \mathrm{W}$ is the mass of the leaking liquid $(\mathrm{kg}), \rho$ is the density of the liquid $\left(\mathrm{kg} / \mathrm{m}^{3}\right)$, and $\mathrm{H}_{\min }$ is the minimum liquid thickness $(\mathrm{m})$. 
The calculation of the minimum width of the buffer platform in Dapu is based on a $20 \mathrm{~m}^{3}$ leakage. According to Formula (3), $\mathrm{W}$ is $20,000 \mathrm{~kg}, \rho$ is $1000 \mathrm{~kg} / \mathrm{m}^{3}$, and the vegetation type is grassland, $\mathrm{H}_{\min }$ is $0.02 \mathrm{~m}$, so the leakage area is $1000 \mathrm{~m}^{2}$. Assuming that the liquid pool is $120^{\circ}$ and fan-shaped, the radius is $30.9 \mathrm{~m}$.

In summary, the width of the vegetation buffer platform in Dapu is $30-50 \mathrm{~m}$, the width of the mixed Salix matsudana and herbs strip is $20 \mathrm{~m}$, and the width of the Salix integra strip is $10-30 \mathrm{~m}$.

\subsubsection{The Environmental Efficiency of the Vegetation Buffer Platform}

The environmental efficiency of the vegetation buffer platform is mainly focused on sediment removal and coastal pollution isolation.

About 0.2 million $\mathrm{m}^{3}$ of sediment on the left bank of Dapu, accounting for about $13 \%$ of the total sediment in Dapu, was used for the construction of the vegetation buffer platform. The turbidity of the surface water in the downstream section of Dapu after two floods with the close flow in 2013 and 2018, before and after the construction of the platform, was measured. The turbidity of the surface water in 2013 was 190.00 NTU, while in 2018, it was 145.34 NTU. The removal of sediment had a positive effect on turbidity reduction.

In addition to suspended solids (SS), nitrogen, phosphorus, and other nutrients, heavy metals, such as $\mathrm{Pb}$ and $\mathrm{Cr}$, and toxic organic substances, such as oil and grease, gasoline hydrocarbons (PHC), and polycyclic aromatic hydrocarbons (PAHs) are the main pollutants of highway pavement runoff. SS is the main carrier of heavy metals in runoff. The high SS removal efficiency of the buffer platform also leads to a high heavy metal removal efficiency. Research by Liu et al. [54] showed that the average removal efficiency of $\mathrm{Pb}$ and $\mathrm{Cr}$ could reach $83.5 \%$ and $93.91 \%$, respectively, with a $4 \mathrm{~m}$ wide arbor-herb mixed vegetation buffer strip. The width of the Dapu vegetation buffer platform is wider, so the removal effect could be higher than that of the above study. There is a lack of relevant research on the interception efficiency of buffer strips for toxic organic substances.

\section{Conclusions}

1. The distribution of sediment along the thalwegs of the three tributaries is similar to the delta sedimentation. Affected by flood scouring and deposition during the drying period, the variations in the sediment thickness in the top-set region along the thalwegs are consistent with that of the section width, showing similar characteristics to the scouring and deposition of rivers.

2. As the inflow bay, Dapu is the crucial area of sediment deposition of the Biliu River. From the convex bank to the inside of the bay, the hydrodynamic force of the sediment gradually weakens, and the thickness shows a gradually increasing trend. Sediment in the convex bank has high sand content, mainly from the bed load of the Biliu River. The sediment near the main stream and slightly inside the bay is mainly from the suspended load and bed load of the Biliu River. The sediment inside the bay is from the suspended load of the Biliu River and the village flood runoff.

3. The removal of sediment from the water-level-fluctuating zone can reduce sediment migration downstream, and it is also conducive to the interception of new sediment. It is an effective method for the in situ utilization of sediment for vegetation buffer platform construction, which can isolate coastal pollution. The vegetation buffer platform in Dapu can reduce the sediment entering the reservoir and have good removal effects on nutrients and heavy metals from National Highway 305. 


\begin{abstract}
Author Contributions: Conceptualization, S.X.; methodology, S.X. and G.S.; validation, Y.L.; formal analysis, G.S., Y.L., H.Y. and B.M.; investigation, G.S., Y.L., H.Y. and B.M.; data curation, Y.L.; writingoriginal draft preparation, G.S.; writing — review and editing, G.S.; visualization, G.S.; supervision, S.X.; project administration, S.X.; funding acquisition, S.X. All authors have read and agreed to the published version of the manuscript.
\end{abstract}

Funding: This research was funded by the National Natural Science Foundation of China, grant number 51879031.

Institutional Review Board Statement: Not applicable.

Informed Consent Statement: Not applicable.

Conflicts of Interest: The authors declare no conflict of interest.

\title{
References
}

1. Yin, X.A.; Yang, Z.F.; Petts, G.E.; Kondolf, G.M. A reservoir operating method for riverine ecosystem protection, reservoir sedimentation control and water supply. J. Hydrol. 2014, 512, 379-387. [CrossRef]

2. Basson, G. Management of siltation in existing and new reservoirs. General Report. In Proceedings of the 23rd Congress of the International Commission on Large Dams, Large Dams, Brasilia, Brazil, 25-29 May 2009.

3. Dams, W.C.O. The Report of the World Commission on Dams; Earthscan Publications: London, UK, 2000.

4. Fu, W.J.; Liu, X.H.; Gong, W.W.; Hou, J. Assessing the Mutagenic Potential of Surface Sediments from Beijing Guanting Reservoir to Salmonella typhimurium. Soil Sediment Contam. 2015, 24, 306-324. [CrossRef]

5. Schleiss, A.J.; Franca, M.J.; Juez, C.; De Cesare, G. Reservoir sedimentation. J. Hydraul. Res. 2016, 54, 595-614. [CrossRef]

6. Qiwei, H.; Mingmin, H. A mathematical model for reservoir sedimentation and fluvial processes. Int. J. Sediment Res. 1990, 2, 43-84.

7. Kostic, S.; Parker, G. Progradational sand-mud deltas in lakes and reservoirs. Part 1. Theory and numerical modeling. J. Hydraul. Res. 2003, 41, 127-140. [CrossRef]

8. Sloff, C.J. Sedimentation in Reservoirs. Ph.D. Thesis, Technische Universiteit Delft, Delft, The Netherlands, 1998.

9. Fan, J.; Morris, G.L. Reservoir sedimentation. I: Delta and density current deposits. J. Hydraul. Eng. 1992, 118, 354-369. [CrossRef]

10. Lai, S.Y.; Capart, H. Reservoir infill by hyperpycnal deltas over bedrock. Geophys. Res. Lett. 2009, 36. [CrossRef]

11. Bak, Ł.; Dabkowski, S.L. Spatial distribution of sediments in Suchedniów reservoir. J. Water Land Dev. 2013, 19, 13-22. [CrossRef]

12. Mohammadzadeh-Habili, J.; Heidarpour, M. New Empirical Method for Prediction of Sediment Distribution in Reservoirs. J. Hydrol. Eng. 2010, 15, 813-821. [CrossRef]

13. Jothiprakash, V.; Garg, V. Reservoir sedimentation estimation using artificial neural network. J. Hydrol. Eng. 2009, 14, 1035-1040. [CrossRef]

14. Castillo, L.; Carrillo, J.; Álvarez, M. Complementary methods for determining the sedimentation and flushing in a reservoir. J. Hydraul. Eng. 2015, 141, 05015004. [CrossRef]

15. Banasik, K.; Skibinski, J.; Gorski, D. Investigation on Sediment Deposition in a Designed Carpathian Reservoir; IAHS Publication: Wallingford, UK, 1993; p. 101.

16. Manenti, S.; Sibilla, S.; Gallati, M.; Agate, G.; Guandalini, R. SPH simulation of sediment flushing induced by a rapid water flow. J. Hydraul. Eng. 2012, 138, 272-284. [CrossRef]

17. Juez, C.; Lacasta, A.; Murillo, J.; García-Navarro, P. An efficient GPU implementation for a faster simulation of unsteady bed-load transport. J. Hydraul. Res. 2016, 54, 275-288. [CrossRef]

18. Hui-cheng, Z.; Fu-xing, W.; Guo-hua, L. Decision-making on reservoir flood control level and its control manner in post-flooding seasons for Biliuhe Reservoir. Adv. Water Sci. 2009, 6, 857-862.

19. Qin, G.; Liu, J.; Wang, T.; Xu, S.; Su, G. An integrated methodology to analyze the total nitrogen accumulation in a drinking water reservoir based on the SWAT model driven by CMADS: A case study of the Biliuhe reservoir in Northeast China. Water 2018, 10, 1535. [CrossRef]

20. Kondolf, G.M.; Gao, Y.X.; Annandale, G.W.; Morris, G.L.; Jiang, E.H.; Zhang, J.H.; Cao, Y.T.; Carling, P.; Fu, K.D.; Guo, Q.C.; et al. Sustainable sediment management in reservoirs and regulated rivers: Experiences from five continents. Earths Future 2014, 2, 256-280. [CrossRef]

21. Shiguo, X.; Guangyu, S.; Tianxiang, W.; Huijuan, Y.; Jianwei, L. A Gravity Type Anti Tilting Sediment Sounding Device and Its Application Method. CN108801107A, 5 June 2018.

22. Yu, H.; Xu, S.; Tian, W.; Zhu, L.; Sun, Y. Impact of long-term water level fluctuation on the distribution, transport, and fate of phosphorus in reservoir sediment. Environ. Sci. Pollut. Res. 2019, 26, 33146-33156. [CrossRef] [PubMed]

23. Caputo, F.; Clogston, J.; Calzolai, L.; Rosslein, M.; Prina-Mello, A. Measuring particle size distribution of nanoparticle enabled medicinal products, the joint view of EUNCL and NCI-NCL. A step by step approach combining orthogonal measurements with increasing complexity. J. Control. Release 2019, 299, 31-43. [CrossRef]

24. Terry, J.P.; Goff, J. Megaclasts: Proposed revised nomenclature at the coarse end of the udden-wentworth grain-size scale for sedimentary particles. J. Sediment. Res. 2014, 84, 192-197. [CrossRef] 
25. Liu, J.; Li, Y.; Shi, X.; You, X.; Sun, B.; Chen, N. Grain size characteristics and distribution regularities of typical river sediments in Haihe River Basin. Water Resour. Prot. 2017, 33, 9-19.

26. Pejrup, M. The triangular diagram used for classification of estuarine sediments: A new approach. In Tide-Influenced Sedimentary Environments and Facies; Pergamon Press: Oxford, UK, 1988; pp. 289-300.

27. Petkovic, S.; Sekulic, G. Erosion and sedimentation processes in the Bojana River Delta at the Adriatic Sea. J. Coast. Conserv. 2019, 23, 39-47. [CrossRef]

28. Fang, Y.; Zhao, W.; Li, W. The particle size profiles of phytoplankton in general reservoirs in Liaoling Province. J. Dalian Ocean Univ. 2013, 28, 390-394.

29. Wang, D.W.; Liu, X.F.; Ji, Z.W.; Dong, Z.D.; Hu, H.H. Influence of flocculation on sediment deposition process at the Three Gorges Reservoir. Water Sci. Technol. 2016, 73, 873-880. [CrossRef] [PubMed]

30. De Cesare, G.; Lafitte, R. Outline of the historical development regarding reservoir sedimentation. In Proceedings of the 32nd IAHR Congress, Harmonizing the Demands of Art and Nature in Hydraulics, Venice, Italy, 1-6 July 2007.

31. Wang, Y.; Ye, R. Study on sediment discharge with two-value relationship. J. Sediment Res. 2018, 43, 7-12.

32. Hu, C.; Xujian, C.; Jiangno, C. Spatial distribution and its variation process of se dimentation in Yellow River. J. Hydraul. Eng. 2008, 39, 518-527.

33. Li, T.; Zhang, J.; Li, S.; Ma, H.; Jiang, S. Discussion on non-equilibrium sediment transport law of turbidity current under muddy lake interface changes in reservoir. J. Hydroelectr. Eng. 2013, 32, 148-152.

34. Fan, J.; Morris, G.L. Reservoir sedimentation. II: Reservoir desiltation and long-term storage capacity. J. Hydraul. Eng. 1992, 118, 370-384. [CrossRef]

35. Migeon, S.; Savoye, B.; Zanella, E.; Mulder, T.; Faugères, J.-C.; Weber, O. Detailed seismic-reflection and sedimentary study of turbidite sediment waves on the Var Sedimentary Ridge (SE France): Significance for sediment transport and deposition and for the mechanisms of sediment-wave construction. Mar. Pet. Geol. 2001, 18, 179-208. [CrossRef]

36. Tarekegn, T.; Toffolon, M.; Righetti, M.; Siviglia, A. Modelling suspended sediment wave dynamics of reservoir flushing. In Proceedings of the Reservoir sedimentation-Special Session on Reservoir Sedimentation of the 7th International Conference on Fluvial Hydraulics, River Flow 2014, Lausanne, Switzerland, 3-5 September 2014; pp. 163-173.

37. Jin, K.-R.; Ji, Z.-G. Case study: Modeling of sediment transport and wind-wave impact in Lake Okeechobee. J. Hydraul. Eng. 2004, 130, 1055-1067. [CrossRef]

38. Guang, H.; Shenliang, C.; Jing, H.U. Sediment characteristics and its relationship to hydrodynamic on nanhui subfluvial flat. Trans. Oceanol. Limnol. 2008, 1,32-38.

39. Li, L.; Lu, X.; Chen, Z. River channel change during the last 50 years in the middle Yangtze River, the Jianli reach. Geomorphology 2007, 85, 185-196. [CrossRef]

40. Spanjaard, G. Recent Erosion and Sedimentation Processes in the Geul River. Master's Thesis, Vrije Universiteit Amsterdam, Amsterdam, The Netherlands, 2004.

41. Jiongxin, X. Study of sedimentation zones in a large sand-bed braided river: An example from the Hanjiang River of China. Geomorphology 1997, 21, 153-165. [CrossRef]

42. Balestrini, R.; Arese, C.; Delconte, C.A.; Lotti, A.; Salerno, F. Nitrogen removal in subsurface water by narrow buffer strips in the intensive farming landscape of the Po River watershed, Italy. Ecol. Eng. 2011, 37, 148-157. [CrossRef]

43. Li, B.; Yuan, X.Z.; Xiao, H.Y.; Chen, Z.L. Design of the dike-pond system in the littoral zone of a tributary in the Three Gorges Reservoir, China. Ecol. Eng. 2011, 37, 1718-1725. [CrossRef]

44. Abu-Zreig, M.; Rudra, R.P.; Whiteley, H.R.; Lalonde, M.N.; Kaushik, N.K. Phosphorus removal in vegetated filter strips. J. Environ. Qual. 2003, 32, 613-619. [CrossRef] [PubMed]

45. Schmitt, T.J.; Dosskey, M.G.; Hoagland, K.D. Filter strip performance and processes for different vegetation, widths, and contaminants. J. Environ. Qual. 1999, 28, 1479-1489. [CrossRef]

46. Yuan, Y.P.; Bingner, R.L.; Locke, M.A. A Review of effectiveness of vegetative buffers on sediment trapping in agricultural areas. Ecohydrology 2009, 2, 321-336. [CrossRef]

47. Zhang, X.Y.; Liu, X.M.; Zhang, M.H.; Dahlgren, R.A.; Eitzel, M. A Review of Vegetated Buffers and a Meta-analysis of Their Mitigation Efficacy in Reducing Nonpoint Source Pollution. J. Environ. Qual. 2010, 39, 76-84. [CrossRef]

48. Sweeney, B.W.; Newbold, J.D. Streamside forest buffer width needed to protect stream water quality, habitat, and organisms: A literature review. J. Am. Water Resour. Assoc. 2014, 50, 560-584. [CrossRef]

49. Cao, X.Y.; Song, C.L.; Xiao, J.; Zhou, Y.Y. The Optimal Width and Mechanism of Riparian Buffers for StormWater Nutrient Removal in the Chinese Eutrophic Lake Chaohu Watershed. Water 2018, 10, 1489. [CrossRef]

50. Dosskey, M.G.; Vidon, P.; Gurwick, N.P.; Allan, C.J.; Duval, T.P.; Lowrance, R. The Role of Riparian Vegetation in Protecting and Improving Chemical Water Quality in Streams1. J. Am. Water Resour. Assoc. 2010, 46, 261-277. [CrossRef]

51. Yang, B. The Control Effect of Riverside Buffer Zone on Non-point Source Pollution of Liaohe River. Ph.D. Thesis, Jilin University, Changchun, China, 2018.

52. Barling, R.D.; Moore, I.D. Role of buffer strips in management of waterway pollution-A review. Environ. Manag. 1994, 18, 543-558. [CrossRef] 
53. Delgado, A.N.; Periago, E.L.; Viqueira, F.D. Vegetated filter strips for waste-water purification-A review. Bioresour. Technol. 1995, 51, 13-22. [CrossRef]

54. Liu, H.W.; Liang, H.; Gao, W.F.; Shen, H.L.; Gao, D. Purification Effect of Heavy Metal by Different Vegetative Configurations in Buffer Strips. Chin. J. Soil Sci. 2018, 49, 727-735. 